\title{
Role of Ahara in graceful aging.
}

\section{Shukla Sonali Viraj**1, Shukla Viraj Vinayak ${ }^{2}$, Patil Monika Dhiraj ${ }^{3}$}

1. Professor \& HOD, Dept of Kriyasharir,

2. Professor, Dept of Kayachikitsa, Mobile No-9822936193; Email-Id - rajvishukla@ gmail.com.

3. Professor, Dept of Samhita \& Siddhanta, Mobile No.-8050467172

L. K. R. Ayurved College, Gadhinglaj, Dist. Kolhapur, Maharashtra.

*Corresponding Author: Ph. No.: 9420522527; Email-Id: sonali.shukla2009@ gmail.com

\begin{abstract}
-
Aging has become an important issue in developing countries. Ageing is an inevitable process. Although one cannot escape from this reality but one can be able to age gracefully. Ayurveda and it principles can play an important role in to relieve the hardships of old age. As Ahara, Nidra and Bramhacharya are three pillars of Life, Certain Dietary rules and sleeping pattern can increase healthy life span and prevent the development of diseases. The key to balance Vatadosha in old age is regularity, rest and warmth One should pay equal attention to physical as well as mental health. Depression is also a very common problem in old age. Depression can hamper digestive one should adopt capacity of an individual. Sattvik ahara, fresh and hot food, green leafy vegetables \& seasonal fruit, proper nidra as part and parcel of old age. Rasayan chikitsa, Sattvavajay chikitsa, yoga, can add years to the life of old persons.
\end{abstract}

Keywords: Aging, Ahara, depression, Sattavajya chikitsa, Yoga.

\section{Introduction-}

Aging is an inevitable process and one cannot found escape from it. Aging has become an important issue in developing countries as 50 percent of its population is above 60 in many countries and its proportion will increase to 80 percent by 2050 . Old age is an autoimmune disease. Old age is caused by repeated indulgence in sensory pleasures, whose wear and tear on the body destroys ojas. The faster you live, the faster you will deteriorate. Hummingbirds flit just a few seasons, but tortoises plod along for decades and centuries. Longevity requires slowness, for a slow life. Permits your protective aura to interpose itself between you and the outside world. In this faster era, Ayurveda and its principles can play an important role to relieve the hardships of old age. Aging is a complex process with multiple manifestations at the molecular, cellular, organ and whole organism level. It produces observable changes in structure and function and increases vulnerability to environmental stress and disease. Although many millions of new cells normally are produced each minute, several kinds of cells in the body-heart muscle cells, skeletal muscle cells and nerve cells do not 
divide because they are arrested permanently in the Go phase. Normal cells grown outside the body divide only a certain number of times and then stop. Many other cell type have only a limited capability to divide. It suggest that cessation of mitosis is a normal genetically programmed event. According to this view, "Aging genes are part of the genetic blueprint at birth. These genes have an important function in normal cells but their activities slow over time."

\section{Materials and Methods-}

As the number of aged people is gradually increasing due to general improvement in health, preventive, curative and rehabilitative measures have to be taken for geriatric problem Due to dominance of Vatadosha in Vardhakyaavastha rate of degenerative changes increases, digestive power decreases as a result of it sharirik and mansik bal also become less. Dietary an genetic alternations can increase healthy life-span and prevent the development of dysregulated systems. Thomas Edison says that the doctor of the future will give no medicine, but will instruct his patients in care of the human frame in diet and in the cause and prevention of disease. In Ayurveda the diet is considered to be one of the most important tools to achieve balance of both body and mind. As old age people faces more of mental and physical problems, appropriate diet is essential to get rid of it. Ayurveda doesn't distinguish between food and medicine and approach of Ayurvedic diet is holistic. Food is medicine and the balanced diet in old age can be perfectly safe and effective treatment. Modern research has proven the there are two guaranteed ways to live longer i.e. decrease your body temperature and decrease your food intake. The mechanisms responsible for life span expansion are "Food" sensors typically activated in situations of food shortage, such as IGF ( Insulin like growth factor ) / insulin and the TOR (Target of rapamycin ) pathways. Accordingly a reduction in food intake without malnutrition extends the life span by $10-15 \%$ diverse organisms from yeast to Rhesus monkeys. When 20 years, $30 \%$ dietary restrictions applied to adult Rhesus monkey was shown to be associated with reduced signs of aging and higher longevity. In humans, dietary restriction is effective against obesity and reduces insulin resistance, inflammation, blood pressure C-reactive protein and intima-media thickness of the carotid arteries. An intresting effect of caloric restriction in

humans is mitochondrial biogenesis. Mitochondrial dysfunction has emerged as a potentially important underlying contributor to aging.

Glucose, the most abundant sugar in the body, plays a role in the aging process. It haphazardly added to proteins inside and outside cells forming reversible cross-links between adjacent protein molecules With advancing age, more cross-links form which contributes to the stiffening and loss of elasticity that occurs in aging tissues.

Ideally diet should be individually designed, according to every person's unique body constitution but also to our specific state of health, age, agni, season, climate, lifestyle and stress level. Diet should be accordance with our harmonious behavior coming naturally from inside rather than having to be enforced from the outside. Good digestion and eating according to our unique body constitution are the cornerstones in Ayurveda for maintainning good health in all ages. Effectively it means knowing how to safeguard our personal freedom understanding our inner rhythms, recognizing our innate self-healing powers and learning how to nourish ourselves.

The guidelines for healthy eating in old age are as follows. 
1. Due to predominance of Vata dosha in old age as functioning of agni is impaired one should take laghu and sattvik ahar. Indigested food leads to Ama and amadosha is the root cause of all disease.

2. Regulate eating and sleeping patterns as much as possible so that body can adjust without stress. As Aahar and Nidra are considered as pillars for healthy life. Sleep is also important for physical as well as mental health.

3. Sattvic food nourishes the body and keeps it in a peaceful state. It gives clarity improves concentration, purifies the mind and makes it more tranquil. Milk, ghee, homemade dahi, green leafy vegetables and Takra should be consumed regularly.

4. Use sugar and salt in moderatio only. Choose food low in fat saturated fat and cholesterol.

5. As eating primarily plant based diet consumed fewer calories than the other things we eat. Vegetarians are notably healthier than carnivores and they live longer also. The risk of heart disease and cancer is greater if one consumes more of red meat.

6. Although energy requirements declines with age but the nutrient requirements remain the same hence nutrient dense foods should be consumed

7. Avoid all kinds of junk food. Eat only hot, fresh, less spicy preferably home made food no leftovers, no canned food. No frozen food as they are hard to digest. Eat plenty of vegetable and seasonal fruits according to Prakriti.
8. Emotions and thinking patterns have the effect on digestion. In the same way wrong digestion will upset our mind and emotions. While taking food, We need to be mentally in the state of happiness While eating one should enjoy the tastes, the appearance, the smell, the textures etc. which gives emotional satisfaction and balance.

9. Avoid overstimulation (T.V., computer, loud noises, crowds and worrying.)

10. The key to balance Vata dosha in old age is regularity, rest and warmth. Vata is a dosha that quickly goes out of balance but also very quickly goes back into balance. It is relatively easy to recover from disbalanced Vata by following dietary advices. Drink worm water throughout the day.

11. Do Abhagya daily with sesame or almond oil It provides strength and improves digestive capacity.

12. Take small walks preferably in nature. Listen to classical music and songs as it pacifies Vata.

13. Yoga is highly recommended and also breathing exercises such as Pranayama and Mantra chanting. Meditation also helps to keep calm and relieves unnecessary stress and anxiety.

14. Rejuvenation is the first step in the direction of immortality. Amalaki, Haritaki, Shatavari, Ashwagandha, Pomegranate, Tulsi are the some dravya boost immune system.

\section{Discussion \& Conclusion -}

Old age is mainly a social problem but as our cultural and social pattern of life is different from the West. The solution lies in inculcating a feeling in the elderly that they are wanted and needed by others and are useful to 
society. Everyone has to go through this life cycle. Some feel young at 90 , some are tired of life at 20 . So our age is not determined by the date on the calendar but by the mind. Depression is also a common problem of old age. It may be precipitated by psychosocial factors like retirement, economic deprivation, loss of near and dear ones, loneliness or drug induced.

\section{Conclusion -}

The motto of Geriatric practice should be add life to years and not merely years to life. Health does not always come only from medicine. Most of the time it comes from peace of mind, peace in the heart and peace of soul. It comes from laughter and love. Expecting and accepting are two sides of life where expecting ends in tears in tears while accepting makes you cheers. Accept the life, the way it comes. With Regular eating and sleeping patterns, taking food according to your prakriti helps for graceful aging. According to Sushru Jara is Swabhavbalpravrut, Vyadhi bưt Panchkarma and Rasayan therapy also helps for graceful aging.

\section{References:}

1. Kaveraj Dr. Ambikadatta Shastri, Sushrut Samhita, Part-I, Chaukhamba Sanskrit Sansthan, Page No. 101.

2. Harrison's principles of internal medicine, $18^{\text {th }}$ edition, Volume-I, page No. 585.

3. Dr. Anil K. Mehta, Ayurveda \& Dietetics, First edition, Chaukhamba Sanskrit Pratisthan, Page No. 128, 121.

4. Mahajan \& Gupta, Textbook of Preventive \& Social medicine, Revised by Ravindranath Roy, fourth edition, Jaypee brothers Medical Publishers (P), LTD. Page No.638,639.

5. Sujit R. Chaudhari, Concise Medical Physiology, $5^{\text {th }}$ edition, New Central book Agency, Page No.394, 95.

6. Dr. Robert E. Svoboda, Prakritiyour Ayurvedic constitution, First edition, Motilal Banarsidas, Page No. 162.

7. Harisadashiv Shastri Paradkar, Astangahrdaya, Chaukhamba Surbharati Prakashan, Page No. 16.

Role of Ahara in graceful aging.

Shukla Sonali Viraj, Shukla Viraj Vinayak, Patil Monika Dhiraj

Ayurlog: National Journal of Research in Ayurved Science- 2018; (6)(6): 1-4 